\title{
Limitations in the isolation and stimulation of splenic mononuclear cells in a dasyurid marsupial, Phascogale calura
}

\author{
C. Letendre, L. J. Young and J. M. Old ${ }^{*}$
}

\begin{abstract}
Objective: Marsupials suffer from an increasing number of stressors in this changing world. Functional studies are thus needed to broaden our understanding of the marsupial immune system. The red-tailed phascogale (Phascogale calura) is a small Australian marsupial previously used in descriptive immunological studies. Here, we aimed to develop functional assays by isolating and stimulating blood and spleen mononuclear cells in vitro.

Results: While peripheral blood mononuclear cell (PBMC) were relatively easy to isolate, only $10^{5}$ mononuclear cells ( $>90 \%$ purity and $>75 \%$ viability) could be recovered from the spleen, independently of the sex and age of the animal or the centrifugation time and speed tested. The pores of the mesh sieve used for tissue homogenization might have been too big to yield a single cell suspension. Nevertheless, in spite of the overall low number of cells recovered, PBMC and splenic mononuclear cells were successfully activated in preliminary trials with phytohemaglutinin. This activation state was evidenced by a change in shape and the presence of small cell aggregations in the mitogenstimulated cultures. A non-radioactive colorimetric assay was also performed to confirm cell proliferation in these wells. This work highlights the importance of developing and reporting detailed methodological protocols in nontraditional research species.
\end{abstract}

Keywords: Marsupials, Dasyurid, Spleen, PBMC, Mononuclear cells, Cell culture, Mitogen, Phytohemaglutinin

\section{Introduction}

Marsupials suffer from environmental and anthropogenic stressors that pose pressure on their immune system [1, 2]. Functional immunological studies are thus needed to develop relevant conservation strategies. The marsupial immune system has long been regarded as 'primitive', with reports of weak or delayed adaptive responses compared to eutherians [3-13]. However, these differences might simply be due to the use of suboptimal assay conditions. There is now a growing body of evidence suggesting that the marsupial immune system is just as intricate and complex as that of eutherians [14].

Lymphocytes proliferate and become activated in response to antigens encountered in secondary lymphoid organs (e.g. spleen). Activated lymphocytes $\left(\mathrm{CD}^{+} \mathrm{T}\right.$

*Correspondence: J.Old@westernsydney.edu.au

School of Science and Health, Western Sydney University, Locked Bag

1797, Penrith, NSW 2751, Australia cells in particular) produce cytokines and these immuneregulatory molecules determine the type of response generated [14]. Although mitogen stimulation induces non-specific activation, these assays have been used extensively in marsupials to investigate lymphocyte 'fitness' and their proliferative capacities (Table 1). Mitogen stimulation assays can be conducted on total splenocytes. However, characterization of the lymphocyte cytokine profile in response to certain stimuli is facilitated by the use of isolated mononuclear cells. In eutherians, splenic mononuclear cells are commonly isolated by density gradient separation after mechanical disruption and passage on a mesh sieve [15]. While some work has been done with marsupial peripheral blood mononuclear cells (PBMC), mononuclear cells have only been isolated occasionally from lymphoid tissues (Table 1). This is due in part to the ethical limitations associated with collecting tissues from threatened/endangered animals, but most 
Table 1 Mitogen stimulation in marsupials

\begin{tabular}{|c|c|c|c|c|}
\hline Species & Tissue or cell type & Cell stimulant & Application & Refs. \\
\hline Dendrolagus matschiei & Whole blood & PHA, ConA, PWM & {$[3 \mathrm{H}]$-thymidine } & {$[8]$} \\
\hline Didelphis virginiana & Blood leukocytes & PHA, ConA, PWM & [3H]-thymidine & [13] \\
\hline \multirow[t]{3}{*}{ Macropus eugenii } & PBMC, spleen MC and LNMC & $\mathrm{PHA}$ & [3H]-thymidine and MTT & {$[25]$} \\
\hline & LNMC & PHA, ConA & RNA extraction & {$[26,27]$} \\
\hline & PBMC, LNMC & Zimosan, PHA, LPS, PWM & RNA extraction & {$[28-31]$} \\
\hline \multirow[t]{3}{*}{ Monodelphis domestica } & PBMC & ConA, PHA, PWM & {$[3 \mathrm{H}]$-thymidine } & {$[32]$} \\
\hline & $\begin{array}{l}\text { Whole blood, spleen, LN, thymus, } \\
\text { peritoneal M } \phi \text {, skin }\end{array}$ & PHA, ConA, PWM, LPS & [3H]-thymidine & {$[33,34]$} \\
\hline & Whole blood & ConA & {$[3 \mathrm{H}]$-thymidine } & {$[6]$} \\
\hline Onychogalea fraenata & Spleen MC & PHA & RNA extraction & {$[31]$} \\
\hline Perameles gunnii & PBMC & ConA, PHA, PWM, LPS & [3H]-thymidine & {$[35]$} \\
\hline \multirow[t]{4}{*}{ Phascolarctos cinereus } & Whole blood, PBMC & PHA and ConA, PWM, LL, jacalin, PA and LPS & [3H]-thymidine & {$[9]$} \\
\hline & PBMC & Ionomycin, PMA & Flow cytometry & {$[36]$} \\
\hline & PBMC & PMA and ionomycin, PMA and PHA, ConA & RNA extraction & {$[37,38]$} \\
\hline & PBMC & PMA and ionomycin, C. pecorum & RNA extraction & {$[39-41]$} \\
\hline \multirow[t]{2}{*}{ Sarcophilus harrisii } & PBMC & ConA, PHA, PWM, LPS & {$[3 \mathrm{H}]$-thymidine } & {$[35,42]$} \\
\hline & PBMC & $\begin{array}{l}\text { Poly(l:C), LPS, flagellin, imiquimod, CpG, } \\
\text { profiling }\end{array}$ & RNA extraction & {$[43]$} \\
\hline \multirow[t]{2}{*}{ Setonix brachyurus } & PBMC & $\mathrm{PHA}$ & [3H]-thymidine & {$[44]$} \\
\hline & Blood leukocytes, spleen, thymus, LN & PHA, ConA, PWM & [3H]-thymidine & {$[45-47]$} \\
\hline Trichosurus caninus & PBMC & Ionomycin, PMA & Flow cytometry & {$[36]$} \\
\hline \multirow[t]{5}{*}{ Trichosurus vulpecula } & Spleen & PHA & {$[3 \mathrm{H}]$-thymidine } & {$[3,4]$} \\
\hline & PBMC & PHA & [3H]-thymidine & {$[48]$} \\
\hline & PBMC, spleen, AM & M. bovis, LPS, LAM & {$[3 \mathrm{H}]$-thymidine, RNA extraction } & {$[49-51]$} \\
\hline & PBMC & Ionomycin, PMA & Flow cytometry & {$[36]$} \\
\hline & PBMC, spleen MC, LNMC & ConA & {$[3 \mathrm{H}]$-thymidine, RNA extraction } & {$[52]$} \\
\hline
\end{tabular}

AM alveolar macrophages, ConA concanavalin A, CpG CpG oligodeoxynucleotide, LL lentil lectin, LN lymph nodes, LNMC lymph node mononuclear cells, LPS lipopolysaccharides, $M \varphi$ macrophages, $M C$ mononuclear cells, PA protein A, PBMC peripheral blood mononuclear cells, $P H A$ phytohemaglutinin, $P M A$ phorbol myristate acetate, $P W M$ pokeweed mitogen

importantly to the low variety of tools and protocols available for these species [14].

The red-tailed phascogale (Phascogale calura) is an Australian daysurid. This small carnivorous marsupial breeds in captivity, which makes it an ideal research model [16-22]. The species is best known for its particular life history, where males die shortly after the breeding season [23]. In captivity, males survive over one year of age, but become infertile and develop signs of accelerated aging and immunosenescence ([24], unpublished results). Given the important role of lymphocytes in the coordination of adaptive immunity, we aimed to isolate and stimulate these cells in vitro. Here, we show the limitations encountered while standardizing a protocol for isolation and stimulation of phascogale splenic mononuclear cells. The end goal of this research is to investigate the type and magnitude of cytokines produced across different age-sex groups. Demonstration of an impaired lymphocyte function in captive adult males would pave the way for future studies of immunosenescence in marsupials.

\section{Main text \\ Methods \\ Animals}

Red-tailed phascogales were sourced from a captive breeding colony housed in the Western Sydney University (WSU) School of Science and Health Native Mammal Teaching and Research Facility, Richmond, NSW, Australia. Animal care was as per the Australian Code for the Care and Use of Animals for Scientific Purposes and the New South Wales Animal Research Act and its Regulations [24]. Protocols were approved by the WSU Animal Care and Ethics Committee (A11197). All samples were collected opportunistically from clinically healthy animals euthanized during routine population management procedures. 


\section{Cell isolation}

Blood and spleen were collected aseptically, immediately after euthanasia with $\mathrm{CO}_{2}$. Samples were carried to the laboratory in an insulated cooler and were processed within 30 min of collection.

Blood Blood was collected via heart puncture (about $1 \mathrm{ml} /$ animal) and placed into sodium EDTA-coated tubes. PBMC were isolated on a density gradient [25]. Blood was diluted with phenol red-free, endotoxin-free Hanks balanced salt solution with calcium and magnesium (HBSS+) (Sigma, St. Louis, MO, USA). The final $4 \mathrm{ml}$ suspension was layered onto $2 \mathrm{ml}$ Ficoll-Paque (GE LifeSciences, Pittsburgh, PA, USA) (1.077 g/ml). PBMC were collected at the interface after centrifugation $(400 g, 25 \mathrm{~min})$. To confirm isolation of mononuclear cells, smears were made for each layer of the gradient using 2- $\mu$ l drops and Diff-Quik staining (Bacto Laboratories, Australia). PBMC were washed with $\mathrm{HBSS}+$. A tris-buffered ammonium chloride solution $(0.16 \mathrm{~mol} / \mathrm{l}$ ammonium chloride, $0.01 \mathrm{~mol} / \mathrm{l}$ tris(hydroxymethyl) aminomethane (Tris), $\mathrm{pH}$ 7.3) was used for red blood cell (RBC) lysis. After additional washing steps, PBMC were resuspended in 100-200 $\mu$ l culture medium (see below). Cell count and viability were evaluated manually by Trypan blue exclusion. Mononuclear cell purity was assessed on Diff-Quik stained smears.

Spleen The spleen was transported into HBSS+ containing $200 \mathrm{U} / \mathrm{ml}$ penicillin, $200 \mu \mathrm{g} / \mathrm{ml}$ streptomycin and $100 \mu \mathrm{g} / \mathrm{ml}$ gentamicin. It was placed on a sterile 60 -mesh stainless-steel sieve (pore size $250 \mu \mathrm{m}$ ) onto a collector tube, perfused with culture medium, teased apart using micro-dissecting scissors, and gently pushed through the sieve using a syringe plunger. The final volume of the splenic suspension was $4 \mathrm{ml}$. Total WBC counts were determined on an aliquot using Türk's solution $(0.01 \%$ crystal violet, $1 \%$ glacial acetic acid), which lyses RBC and stains leukocytes to assist counting [53]. The splenic suspension was layered onto $2 \mathrm{ml}$ Ficoll-Paque and mononuclear cells were recovered at the interface following centrifugation (see conditions tested in Table 2). Finally, cells were washed and counted as described for PBMC. The recovery rate (\%) corresponds to (number of mononuclear cells isolated)/(total number of WBC) $\times 100$.

\section{Cell culture and stimulation}

Cells were diluted to the desired concentration in Iscove's Modified Dulbecco's Medium (IMDM) with GlutaMAX supplement, $100 \mathrm{U} / \mathrm{ml}$ penicillin, $100 \mu \mathrm{g} / \mathrm{ml}$ streptomycin, $50 \mu \mathrm{g} / \mathrm{ml}$ gentamicin and $5-10 \%$ fetal calf serum (FCS; LifeTechnologies, Carlsbad, CA, USA). Cells were plated in adherent, flat bottom, 96-well plates. Plates were incubated at 35 or $37{ }^{\circ} \mathrm{C}, 5 \% \mathrm{CO}_{2}$ for $24-72 \mathrm{~h}$. Cells were visualized using an Olympus CKX41 microscope. Culture conditions yielding the best viability were selected for the mitogen stimulation assay. Cells were stimulated with phytohemaglutinin from Phaseolus vulgaris (PHA-M; 10, 25 or $50 \mu \mathrm{g} / \mathrm{ml}$; Sigma), based on concentrations reported for other species [3, 9, 25, 34, 35].

\section{Quick Cell Proliferation Assay}

The Quick Cell Proliferation Assay kit II (Abcam, Cambridge, UK) was used to quantify cell proliferation and viability of mitogen-stimulated cells, as per the manufacturer's instructions. The plate was read at $450 \mathrm{~nm}$ using

Table 2 Conditions tested for isolation of splenic mononuclear cells

\begin{tabular}{|c|c|c|c|c|c|c|c|c|}
\hline \multirow[t]{2}{*}{ Date } & \multirow{2}{*}{$\begin{array}{l}\text { Sex (number } \\
\text { of individuals } \\
\text { pooled) }\end{array}$} & \multirow[t]{2}{*}{ Age (months) } & \multicolumn{3}{|c|}{ Conditions tested } & \multicolumn{3}{|l|}{ Spleen cells } \\
\hline & & & Speed $(g)$ & Time (min) & $\mathrm{RBCL}$ & WBC count & Recovery (\%) & Viability (\%) \\
\hline 18 April 2017 & $F(1)$ & 9 & 400 & 25 & No & $3.5 \times 10^{7}$ & 0.5 & 86 \\
\hline 2 May 2017 & $M(1)$ & 10 & 400 & 20 & Yes & $8.9 \times 10^{7}$ & 0.2 & 97 \\
\hline \multirow[t]{2}{*}{22 May 2017} & $M(1)$ & 10 & 400 & 25 & Yes & $1.7 \times 10^{7}$ & 0.6 & 76 \\
\hline & $M(1)$ & 10 & 400 & 25 & Yes & $7.1 \times 10^{7}$ & 1.2 & 82 \\
\hline 29 June 2017 & $F(1)$ & 11 & 400 & 25 & Yes & $6.5 \times 10^{6}$ & 0.5 & 88 \\
\hline 6 July 2017 & $M(2)$ & 12 & 400 & 25 & Yes & $3.2 \times 10^{7}$ & 0.1 & 72 \\
\hline 18 July 2017 & $F(3)$ & 12 & 400 & 25 & Yes & $8.8 \times 10^{7}$ & 0.1 & 88 \\
\hline \multirow[t]{2}{*}{25 July 2017} & $F(2)$ & 12 & 400 & 20 & Yes & $1.9 \times 10^{7}$ & 0.0 & 68 \\
\hline & $M(2)$ & 12 & 400 & 20 & Yes & $5.0 \times 10^{7}$ & 0.1 & 88 \\
\hline \multirow[t]{2}{*}{1 Aug 2017} & $M(2)$ & 13 & 350 & 20 & Yes & $1.4 \times 10^{7}$ & 0.3 & 88 \\
\hline & $M(2)$ & 13 & 400 & 15 & Yes & $1.5 \times 10^{7}$ & 0.2 & 75 \\
\hline 23 Aug 2017 & $F(2)$ & 13 & 400 & 15 & No & $2.3 \times 10^{7}$ & 1.0 & 87 \\
\hline 8 Sept 2017 & $F(2)$ & 14 & 400 & 15 & No & $3.1 \times 10^{7}$ & 0.1 & 78 \\
\hline 4 Oct 2017 & $F(1)$ & 4 & 400 & 15 & No & $2.1 \times 10^{7}$ & 0.7 & 85 \\
\hline
\end{tabular}


a multi-well spectrophotometer (Biorad, Hercules, CA, USA) after $4 \mathrm{~h}$ incubation.

\section{Statistics}

A one-way ANOVA was used to analyze the effect of PHA concentration on PBMC proliferation, and a twoway ANOVA for the effect of cell density and PHA treatment. $p$-values were Bonferroni-adjusted. The effect of PHA stimulation on splenocyte proliferation was analyzed using an independent sample T-test. Analyses were performed with IBM SPSS Statistics software (v.24). $p<0.05$ was considered as statistically significant. Data are mean \pm SEM, unless otherwise stated.

\section{Results and discussion}

\section{Isolation of splenic mononuclear cells}

The protocol used here for isolation of splenic mononuclear cells is based on previous work in the tammar wallaby (Macropus eugenii) [25, 53], but was found to be suboptimal in the phascogale. In this study, only about $10^{5}$ mononuclear spleen cells $(>90 \%$ purity and $>75 \%$ viability) were routinely recovered, independently of the sex and age of the animal or the technical conditions tested (Table 2). The phascogale spleen is obviously much smaller than that of a wallaby, but the number of cells recovered was still low compared to a murine spleen of similar size ([15], personal observation). Marx et al. similarly reported a low cell density for the opossum (Didelphis virginiana) spleen compared to mice [12]. To determine whether the low cell numbers obtained in this study were due to an inherent low cellular density or rather to a suboptimal isolation technique, we evaluated the total number of white blood cells (WBC) in the splenic suspension prior to the density gradient separation. We found that the phascogale spleen contained on average $3.7 \pm 0.7 \times 10^{7} \mathrm{WBC}$, which means that only $0.4 \pm 0.1 \%$ of these cells were effectively recovered (Table 2). In comparison, $>10 \%$ PBMC were routinely recovered under similar conditions: centrifugation of whole blood yielded a clear white band at the interface of the density gradient, which facilitated the recovery of mononuclear cells. Meanwhile, only a diffuse smear in the lower phase of the gradient was obtained with the splenic suspension. Spleen cells are highly heterogeneous: they could vary in their buoyancy and separate non-uniformly on the density gradient. Interestingly though, the number of splenic mononuclear cells recovered remained low with shorter centrifugation times (Table 2; 1 August 2017). This persistent non-uniform cell distribution could be explained by an inadequate homogenization and separation of the splenic tissue on the sieve. A sieve with $200-\mu \mathrm{m}$ pores is typically recommended in mice for preparation of lymphoid cell suspensions [15]. However, we used a $250-\mu \mathrm{m}$ sieve as described in the wallaby [25]. The sieve pores were therefore possibly too big to yield a single cell suspension. In fact, cell clumps were often visualized in smears from the lower phase of the gradient. In contrast, no such clumps were visualized during PBMC isolation. While the pore size of the mesh sieve appears critical for preparation of single cell suspensions, this information is rarely mentioned in the marsupial literature and should be included in future publications. At this stage, it also remains unclear whether the mononuclear cells of the phascogale and wallaby differ in their buoyancy, but this type of interspecies variation is well documented in eutherians [54]. Finally, since most RBC were removed by centrifugation, RBC lysis was eventually eliminated from the protocol to avoid any further cell loss and unnecessary damage (Table 2).

\section{Culture of splenic and peripheral blood mononuclear cells}

Given the low number of cells routinely recovered, the conditions tested for splenic mononuclear cells were based on those determined in pretrials with PBMC. Early standardization work was carried out as a series of small experiments testing only one variable at a time. Temperature was found to affect cell viability in vitro. It was drastically impaired when cells were incubated at $37{ }^{\circ} \mathrm{C}$ $(15 \%$ after $24 \mathrm{~h})$ compared to $35^{\circ} \mathrm{C}(92 \%$ after $48 \mathrm{~h}$, and $76 \%$ after $72 \mathrm{~h}$ ). Lymphoid cells from another dasyurid, the Tasmanian devil (Sarcophilus harrisii), have been cultured similarly at $35{ }^{\circ} \mathrm{C}$ [43]. Marsupials typically have a lower body temperature (by $1.0-3.0^{\circ} \mathrm{C}$ ) and a lower basal metabolic rate (by 30\%) than eutherians [55]. However, marsupial cells are still generally cultured at $37^{\circ} \mathrm{C}$ $[4,9,25,32,36,46]$. The reasons for these interspecies variations remain unclear but may depend on the culture medium/buffer. Moreover, cell viability was densitydependent: good viability was obtained after 48-72 h with relatively high cell densities $\left(0.5-1 \times 10^{6}\right.$ cells $/ \mathrm{ml}$ in $150-200 \mu \mathrm{l})$, as described in the wallaby [52]. Finally, different concentrations of FCS were tested [13], but viability remained unchanged at concentrations above 5\% FCS.

\section{Mitogen stimulation and assessment of proliferation}

PBMC and splenic mononuclear cells progressively adopted an activated, Y-shaped morphology within 4-6 h of PHA stimulation [25]. Numerous small cell aggregations were also present after $24 \mathrm{~h}$ in mitogenstimulated cultures. As accurate cell counts cannot be determined manually by Trypan blue exclusion when cells are aggregated, proliferation assays are routinely used (Table 1). The Quick Cell Proliferation Assay is a non-radioactive colorimetric approach where the amount of dye generated is proportional to the number of living cells [56]. Increased proliferation was observed 

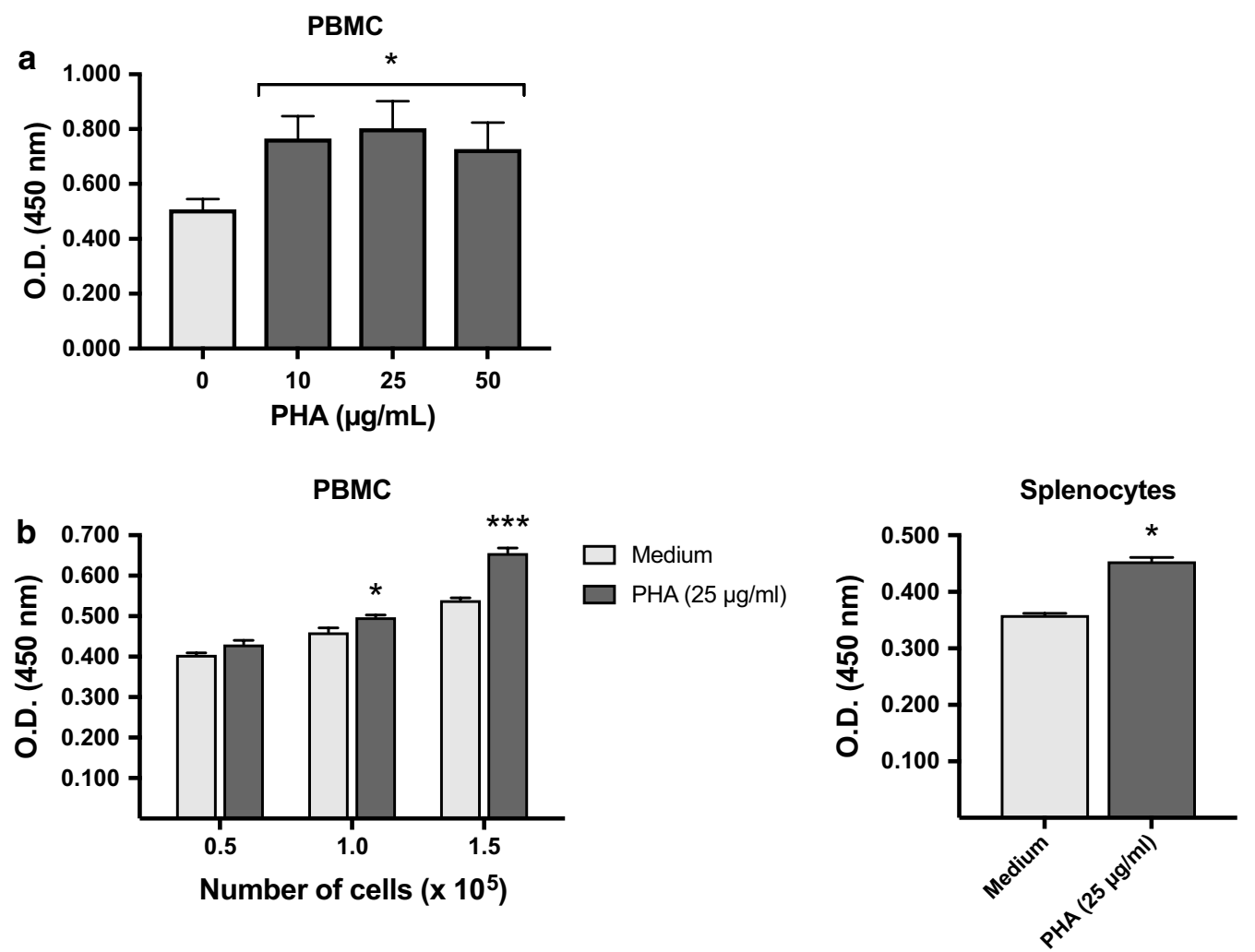

Fig. 1 Cell proliferation in response to stimulation with phytohemaglutinin (PHA). $2 \times 10^{5}$ PBMC were stimulated with different concentrations of PHA (final volume $=150 \mu \mathrm{l}$ ). After $48 \mathrm{~h}$, reagent from the Quick Cell Proliferation Assay kit was added to each well and absorbance of the dye solution was measured at $450 \mathrm{~nm}$ after an additional $4 \mathrm{~h}$ of incubation. The graph shows the dose-response curve obtained for two individuals (a). $0.5-1.5 \times 10^{5}$ PBMC or $1 \times 10^{5}$ splenic mononuclear cells were stimulated with PHA $(25 \mu \mathrm{g} / \mathrm{ml}$; final volume $=150 \mu \mathrm{ll})$ and proliferation was assessed after 48 h using the Quick Cell Proliferation Assay kit, as described in a. Work was performed in duplicates and data are expressed as mean \pm SEM (b). Asterisks indicate a statistically significant difference $\left({ }^{*} p<0.05\right.$ and $\left.{ }^{* * *} p<0.0005\right)$

both in PHA-stimulated PBMC and splenic mononuclear cell cultures $(p=0.020$ and $p=0.023$, respectively) (Fig. 1a, b). However, no dose-response was observed with increasing concentrations of PHA $(p=0.190)$. The strongest effect of mitogen stimulation was observed at high cell densities $(p<0.0005)$ (Fig. 1b). Similar results were obtained with splenic mononuclear cells, although only selected conditions could be tested with this cell type.

\section{Limitations and conclusions}

This work highlights the importance of developing rigorous methodological protocols in non-traditional research species as suboptimal assay conditions are likely to yield biased comparisons with other species. Technical details for isolation of lymphoid cells (sieve pore size, centrifugation time and speed) should be consistently reported in future publications to ensure repeatability across studies. Here, we offer preliminary results showing successful lymphocyte activation and proliferation in response to mitogen stimulation in the phascogale. Future studies investigating the impact of age and sex on lymphocyte function in this species will depend on the capacity to further increase the recovery of mononuclear cells. FACS sorting based on cell size and granularity might be a promising alternative.

\section{Abbreviations}

AM: alveolar macrophages; ConA: concanavalin A; CpG: CpG oligodeoxynucleotide; LL: lentil lectin; LN: lymph nodes; LNMC: Iymph node mononuclear cells; LPS: lipopolysaccharides; M\$: macrophages; MC: mononuclear cells; PA: protein A; PBMC: peripheral blood mononuclear cells; PHA: phytohemaglutinin; PMA: phorbol myristate acetate; PWM: pokeweed mitogen; RBC: red blood cells; WBC: white blood cells.

\section{Authors' contributions}

$C L, L J Y$ and $J M O$ designed the research and analyzed the data; $C L$ performed the experiments; $\mathrm{CL}$ and JMO wrote the paper. All authors read and approved the final manuscript.

\section{Acknowledgements}

We thank Mark Emanuel for technical assistance.

\section{Competing interests}

The authors declare that they have no competing interests. 


\section{Availability of data and materials}

All data generated or analyzed during this study are included in this published article.

\section{Consent for publication}

Not applicable.

\section{Ethics approval and consent to participate}

Animal care was in accordance with the Australian Code for the Care and Use of Animals for Scientific Purposes and the New South Wales Animal Research Act and its Regulations. All protocols were approved by the WSU Animal Care and Ethics Committee (A11197).

\section{Funding}

The School of Science and Health provided financial support for the Small Native Mammal Teaching and Research Facility and the WSU Animal Care and Ethics Committee approved the animal research authorities. CL was supported by Higher Degree Research Funds allocated by WSU School of Science and Health and was the recipient of a Ph.D. Award granted by the Fonds de recherche du Québec-Nature et technologies.

\section{Publisher's Note}

Springer Nature remains neutral with regard to jurisdictional claims in published maps and institutional affiliations.

\section{Received: 6 July 2018 Accepted: 8 October 2018}

Published online: 10 October 2018

\section{References}

1. Acevedo-Whitehouse K, Duffus AL. Effects of environmental change on wildlife health. Philos Trans R Soc Lond B Biol Sci. 2009;364(1534):3429-38.

2. Hing $S$, Narayan E, Thompson RA, Godfrey S. A review of factors influencing the stress response in Australian marsupials. Conserv Physiol. 2014:2:1-17.

3. Moriarty KM. A possible deficiency of cell-mediated immunity in the opossum, Trichosurus vulpecula, in relation to tuberculosis. N Z Vet J. 1973;21(8):167-9.

4. Moriarty KM, Thomas MJ. Absence of lymphokine-enhanced macrophage migration in vitro in the Australian brush-tailed opossum, Trichosurus vulpecula. Vet Immunol Immunopathol. 1986;13(4):365-70.

5. Jansen AM, Leon L, Machado GM, da Silva MH, Souza-Leão SM, Deane MP. Trypanosoma cruzi in the opossum Didelphis marsupialis: parasitological and serological follow-up of the acute infection. Exp Parasitol. 1991:73(3):249-59.

6. Stone WH, Brunn DA, Foster EB, Manis GS, Hoffman ES, Saphire DG, VandeBerg JL, Infante AJ. Absence of a significant mixed lymphocyte reaction in a marsupial (Monodelphis domestica). Lab Anim Sci. 1998;48(2):184-9.

7. Wilkinson R, Kotlarski I, Barton M. Koala lymphoid cells: analysis of antigen-specific responses. Vet Immunol Immunopathol. 1992;33(3):237-47.

8. Montali RJ, Bush M, Cromie R, Holland SM, Maslow JN, Worley M, Witebsky FG, Phillips TM. Primary Mycobacterium avium complex infections correlate with lowered cellular immune reactivity in Matschie's tree kangaroos (Dendrolagus matschiei). J Infect Dis. 1998;178(6):1719-25.

9. Wilkinson R, Kotlarski I, Barton M, Phillips P. Isolation of koala lymphoid cells and their in vitro responses to mitogens. Vet Immunol Immunopathol. 1992;31(1-2):21-33.

10. Taylor DL, Burrell R. The immunologic responses of the North American opossum (Didelphis virginiana). J Immunol. 1968;101(6):1207-16.

11. Rowlands DT. The immune response of adult opossums (Didelphis virginiana) to the bacteriophage f2. Immunology. 1970;18(2):149-55.

12. Marx JJ, Burrell R, Fisher SQ. A study of the afferent and efferent limbs of the immune response in opossums. J Immunol. 1971;106(4):1043-9.

13. Fox DH, Rowlands DTJ, Wilson DB. Proliferative reactivity of opossum peripheral blood leukocytes to allogeneic cells, mitogens, and specific antigens. Transplantation. 1976;21(2):164-7.

14. Belov K, Miller RD, Old JM, Young LJ. Marsupial immunology bounding ahead. Aust J Zool. 2013:61(1):24-40.
15. Kruisbeek AM. Isolation of mouse mononuclear cells. Current Protocols in Immunology. 2000;39(1):1-5.

16. Old JM, Carman RL, Fry G, Deane EM. The immune tissues of the endangered red-tailed phascogale (Phascogale calura). J Anat. 2006:208(3):381-7.

17. Borthwick CR, Old JM. Histological development of the immune tissues of a marsupial, the red-tailed phascogale (Phascogale calura). Anat Rec. 2016;299(2):207-19.

18. Borthwick CR, Young $L J$, McAllan BM, Old JM. Identification of the mRNA encoding interleukin- 6 and its receptor, interleukin- 6 receptor alpha, in five marsupial species. Dev Comp Immunol. 2016;65:211-7.

19. Hermsen EM, Young LJ, Old JM. Major histocompatibility complex Class II in the red-tailed phascogale (Phascogale calura). Aust Mamm. 2016:39(1):28-32

20. Ong OTW, Green-Barber JM, Kanuri A, Young LJ, Old JM. Antimicrobial activity of red-tailed phascogale (Phascogale calura) serum. Comp Immunol Microbiol Infect Dis. 2017;51:41-8.

21. Ong OTW, Young LJ, Old JM. Sequences and expression of pathwayspecific complement components in developing red-tailed phascogale (Phascogale calura). Dev Comp Immunol. 2016:65:314-20.

22. Ong OTW, Young LJ, Old JM. Detection of an active complement system in red-tailed phascogales (Phascogale calura). Comp Clin Pathol. 2015;24(6):1527-34

23. Bradley AJ. Stress and mortality in the red-tailed phascogale, Phascogale calura (Marsupialia: Dasyuridae). Gen Comp Endocrinol. 1987;67(1):85-100.

24. Stannard HJ, Borthwick CR, Ong O, Old JM. Longevity and breeding in captive red-tailed phascogales (Phascogale calura). Aust Mamm. 2013:35(2):217-9.

25. Young $L$, Deane EM. Culture and stimulation of tammar wallaby lymphocytes. Vet Res Commun. 2007:31(6):685-701.

26. Young $L$, Harrison GA. Molecular characterization of interleukin1 Beta in the tammar wallaby (Macropus eugenii). J Vet Med Sci. 2010;72(11):1521-6

27. Young L. Expressed sequence identification and characterization of the cDNA for interleukin-4 from the mitogen-stimulated lymphoid tissue of a marsupial, Macropus eugenii. Vet Immunol Immunopathol. 2011;140(3-4):335-40.

28. Alsemgeest J, Old JM, Young LJ. Molecular characterisation and expression of Interleukin-6 and Interleukin-6 $\Delta 2$ in the Tammar wallaby (Macropus eugenii). Vet Immunol Immunopathol. 2013;155(1-2):139-45.

29. Alsemgeest J, Old JM, Young $L J$. Further characterisation of cytokines in macropod marsupials: IL-10 and IL-10 $\triangle 3$. Cytokine. 2016;88:37-44.

30. Alsemgeest J, Old JM, Young LJ. The macropod type 2 interferon gene shares important regulatory and functionally relevant regions with eutherian IFN-ץ. Mol Immunol. 2015;63(2):297-304.

31. Suthers AN, Old JM, Young LJ. The common gamma chain cytokine interleukin-21 is expressed by activated lymphocytes from two macropod marsupials, Macropus eugenii and Onychogalea fraenata. Int J Immunogenet. 2016;43(4):209-17

32. Infante AJ Samples NK, Croix DA, Redding TS, VandeBerg JL, Stone WH. Cellular immune response of a marsupial, Monodelphis domestica. Dev Comp Immunol. 1991:15(3):189-99.

33. Brozek CM, Ley RD. Production of interleukin-1 in a South American opossum (Monodelphis domestica). Dev Comp Immunol. 1991;15(4):401-12.

34. Brożek CM, Kaleta EW, Kusewitt DF, Ley RD. Proliferative responses of lymphocytes to mitogens in the gray, short-tailed opossum, Monodelphis domestica. Vet Immunol Immunopathol. 1992;31(1):11-9.

35. Stewart NJ, Bettiol SS, Kreiss A, Fox N, Woods GM. Mitogen-induced responses in lymphocytes from platypus, the Tasmanian devil and the eastern barred bandicoot. Aust Vet J. 2008;86(10):408-13.

36. Higgins DP, Hemsley S, Canfield PJ. Assessment of anti-bovine IL 4 and IFN gamma antibodies to label IL4 and IFN gamma in lymphocytes of the koala and brushtail possum. Vet Immunol Immunopathol. 2004;101(3-4):153-60.

37. Maher IE, Griffith JE, Lau Q, Reeves T, Higgins DP. Expression profiles of the immune genes CD4, CD8beta, IFNgamma, IL-4, IL-6 and IL-10 in mitogenstimulated koala lymphocytes (Phascolarctos cinereus) by qRT-PCR. PeerJ. 2014;2:e280. 
38. Maher IE, Higgins DP. Altered immune cytokine expression associated with KoRV B infection and season in captive koalas. PLOS ONE. 2016;11(10):e0163780.

39. Mathew M, Beagley KW, Timms P, Polkinghorne A. Preliminary characterisation of tumor necrosis factor alpha and interleukin-10 responses to Chlamydia pecorum infection in the koala (Phascolarctos cinereus). PLoS ONE. 2013;8(3):e59958.

40. Mathew M, Waugh C, Beagley KW, Timms P, Polkinghorne A. Interleukin 17A is an immune marker for chlamydial disease severity and pathogenesis in the koala (Phascolarctos cinereus). Dev Comp Immunol. 2014;46(2):423-9.

41. Mathew M, Pavasovic A, Prentis PJ, Beagley KW, Timms P, Polkinghorne A. Molecular characterisation and expression analysis of interferon gamma in response to natural Chlamydia infection in the koala, Phascolarctos cinereus. Gene. 2013;527(2):570-7.

42. Kreiss A, Fox N, Bergfeld J, Quinn SJ, Pyecroft S, Woods GM. Assessment of cellular immune responses of healthy and diseased Tasmanian devils (Sarcophilus harrisii). Dev Comp Immunol. 2008;32(5):544-53.

43. Patchett AL, Latham R, Brettingham-Moore KH, Tovar C, Lyons AB, Woods $\mathrm{GM}$. Toll-like receptor signaling is functional in immune cells of the endangered Tasmanian devil. Dev Comp Immunol. 2015;53(1):123-33.

44. Ashman R, Keast D, Stanley NF, Waring $H$. The in vitro response to phytohaemagglutinin (PHA) of leucocytes from intact and thymectomized quokkas. Aust J Exp Biol Med Sci. 1972;50(3):337-45.

45. Ashman R, Keast D. The development of mitogen responses in the quokka, Setonix brachyurus. In: Proceedings of an international symposium on the phylogeny of T and B cells: 1-3 June 1976; New Orleans, Louisiana. 1976. p. 257-66.

46. Ashman RB, Holmes RM, Keast D. The in vitro response to phytomitogens of marsupial leukocytes. Lab Anim Sci. 1976;26(5):777-80.

47. Ashman RB, Holmes RM, Keast D. The effect of neonatal thymectomy on the ontogeny of mitogen responses in the quokka (Setonix brachyurus). Dev Comp Immunol. 1977;1(1):47-57.
48. Baker ML, Gemmell E, Gemmell RT. Physiological changes in brushtail possums, Trichosurus vulpecula, transferred from the wild to captivity. J Exp Zool. 1998;280(3):203-12.

49. Wedlock DN, Aldwell FE, Buddle BM. Molecular cloning and characterization of tumor necrosis factor alpha (TNF-alpha) from the Australian common brushtail possum, Trichosurus vulpecula. Immunol Cell Biol. 1996;74(2):151-8.

50. Wedlock DN, Aldwell FE, Buddle BM. Nucleotide sequence of a marsupial interleukin-10 cDNA from the Australian brushtail possum (Trichosurus vulpecula). DNA Seq. 1998;9(4):239-44.

51. Buddle BM, Aldwell FE, Pfeffer A, de Lisle GW. Experimental Mycobacterium bovis infection in the brushtail possum (Trichosurus vulpecula): pathology, haematology and lymphocyte stimulation responses. Vet Microbiol. 1994;38(3):241-54.

52. Young LJ, Cross ML, Duckworth JA, Flenady S, Belov K. Molecular identification of interleukin-2 in the lymphoid tissues of the common brushtail possum, Trichosurus vulpecula. Dev Comp Immunol. 2012;36(1):236-40.

53. Young LJ. Cellular immune responses of marsupials: family macropodidae. Penrith: University of Western Sydney; 2002. http://p8081-handl e.uws.edu.au.ezproxy.uws.edu.au/1959.7/12869. Accessed 22 Oct 2016.

54. Pertoft H, Laurent TC. Sedimentation of cells in colloidal silica (Percoll). In: Pretlow TG, Pretlow TP, editors. Cell separation: methods and selected applications. New York: Academic Press, Inc.; 1982. p. 115-52.

55. Gaughan JB, Hogan LA, Wallage A. Thermoregulation in marsupials and monotremes. In: Klieve A, Hogan L, Johnston S, Murray P, editors. Marsupials and monotremes Nature's enigmatic mammals. New York: Nova Science Publishers; 2015. p. 85-144.

56. Alessio N, Del Gaudio S, Capasso S, Di Bernardo G, Cappabianca S, Cipollaro M, Peluso G, Galderisi U. Low dose radiation induced senescence of human mesenchymal stromal cells and impaired the autophagy process. Oncotarget. 2015;6(10):8155-66.
Ready to submit your research? Choose BMC and benefit from:

- fast, convenient online submission

- thorough peer review by experienced researchers in your field

- rapid publication on acceptance

- support for research data, including large and complex data types

- gold Open Access which fosters wider collaboration and increased citations

- maximum visibility for your research: over $100 \mathrm{M}$ website views per year

At $\mathrm{BMC}$, research is always in progress.

Learn more biomedcentral.com/submissions 